【U Home Science Extension And Communication Management

Volume 2 | Issue 1 | Jan., 2015 | 58-62
- DOI : 10.15740/HAS/IJHSECM/2.1/58-62

- Visit us : www.researchjournal.co.in

$\mathbf{A}_{\mathbf{R}_{\text {Evew }}}$

\title{
Organizational problems of non-governmental organizations (NGOS)
}

\author{
R. ARUNA* AND S. THANASUNDARI \\ V.V. Vanniaperumal College for Women, VIRUDHUNAGAR (T.N.) INDIA
}

\begin{abstract}
The non-governmental sector is a growing worldwide phenomenon. Organizations across the globe account for growing and impressive figures in employment, revenue, services provided and sheer numbers. Whereas the past years have seen quite a few insolvencies and business collapses caused by management failures. NGOs concerned with development face the management of a complex and diverse range of issues. NGOs face internal management issues, for example questions of strategic planning, budgeting, staffing, and the governing structure of the organization, growth and change within the organization. NGOs also face the management of external relationships, relations with government, the private sector, other NGOs and with their target communities. All of these come to bear on the possibility of NGOs managing development. The effectiveness of NGOs as actors in development and change depends on successful engagement with both internal and external management questions and also on the successful articulation between issues of internal and external management. Although NGOs share many individual characteristics with other sorts of organizations, the various collections of characteristics that are observable in many NGOs create a package that is quite different from most for-profit organizations (FPOs). Some scholars argued; legal constraints, revenue sources, types of personnel, and the nature of governance in NGOs make them unique. There is a growing debate within the non-governmental management literature and the community of non-governmental about whether NGOs should become more "business like".
\end{abstract}

KeY WorDS : NGOs, Organizational problems

View Point Article : Aruna, R. and Thanasundari, S. (2015). Organizational problems of non-governmental organizations (NGOS). Internat. J. Home Sci. Extn. \& Comm. Manage., 2 (1): 58-62.

Article History : Received : 11.09.2014; Accepted : 21.12.2014

\footnotetext{
* Author for correspondence
} 